\title{
Determination of hygrothermal properties of cementitious mortar: The effect of partial replacement of cement by incinerated sewage sludge ash
}

\author{
Krejcirikova, Barbora; Rode, Carsten; Peuhkuri, Ruut Hannele
}

Published in:

Journal of Building Physics

Link to article, DOI:

$10.1177 / 1744259118791202$

Publication date:

2019

Document Version

Peer reviewed version

Link back to DTU Orbit

Citation (APA):

Krejcirikova, B., Rode, C., \& Peuhkuri, R. H. (2019). Determination of hygrothermal properties of cementitious mortar: The effect of partial replacement of cement by incinerated sewage sludge ash. Journal of Building Physics, 42(6), 771-787. https://doi.org/10.1177/1744259118791202

\section{General rights}

Copyright and moral rights for the publications made accessible in the public portal are retained by the authors and/or other copyright owners and it is a condition of accessing publications that users recognise and abide by the legal requirements associated with these rights.

- Users may download and print one copy of any publication from the public portal for the purpose of private study or research.

- You may not further distribute the material or use it for any profit-making activity or commercial gain

- You may freely distribute the URL identifying the publication in the public portal 


\title{
Determination of hygrothermal properties of cementitious mortar: The effect of partial replacement of cement by incinerated sewage sludge ash
}

\author{
Barbora Krejcirikova $^{1}$, Carsten Rode ${ }^{1}$ and Ruut Peuhkuri ${ }^{2}$
}

\begin{abstract}
Two sewage sludge ashes were used as substitutes for cement and their effect on the hygrothermal properties of mortar was examined. Different cement to ash ratios and two ash pre-treatment methods (water washing and grinding) were in focus. The impact of cement replacement by sewage sludge ashes on thermal conductivity, sorption isotherms, water vapour permeability and carbonation was described with standard cement-based mortar as the reference material. Measurement results showed that thermal conductivity decreased by $15 \%$ when $30 \%$ of the cement was replaced by sewage sludge ash. Water vapour permeability increased as the cement to ash ratio was reduced. Sorption was tested by two methods; although differences in the sorption isotherms of mortars were reported when a climatic chamber method was applied, no differences, or only minor differences, were observed with the desiccator method. Measurements revealed that cement-based mortar possessed a higher content of carbonate than cement-ash-based mortar, and it thus appears that the carbonation rate was higher when the cement content was high.
\end{abstract}

\section{Keywords}

Sewage sludge ash, supplementary cementitious material (SCM), thermal conductivity, sorption, water vapour permeability, carbonation

\section{Introduction}

Sewage is the collection of discharge from domestic, medical, commercial and industrial establishments with added rain water. Sewage sludge has been used in agriculture as a fertilizer, due to its high content of phosphorus. More recently, the tendency has been to incinerate sewage sludge (1). The organic matter is combusted and by-products such as $\mathrm{CO}_{2}$, other trace gases and water vapour are produced. However, the process of waste disposal by incineration is not complete since a non-negligible amount of residue of incinerated Sewage Sludge Ash (SSA) remains afterwards. It is estimated that the global

\footnotetext{
${ }^{1}$ Department of Civil Engineering, Technical University of Denmark, Lyngby, Denmark

2 Danish Building Research Institute, Aalborg University, Copenhagen, Denmark
} 
production of SSA is approximately 1.7 million tons annually, mainly from the USA, the EU and Japan, and this quantity is increasing $(2,3)$. Most of the SSA has been landfilled (4-7), even though there have been some exploration of recycling and beneficial resource recovery $(2,4,6,8-17)$. These investigations included the potential use of SSA as a supplementary material in blended cements $(2,18)$, mortar $(11,12,19)$, blocks $(14,20)$ and bricks $(21,22)$. The role of the SSA in mortar can either be as a cement substitute (similar to coal fly ash), as a binder when it possesses some degree of pozzolanic activity, or it may replace sand and thus act as a filler. Such replacement would not only preserve natural resources, but would also significantly contribute to a reduction of $\mathrm{CO}_{2}$ emissions, and to increased energy conservation in the course of cement production and waste handling (2325). These benefits will be substantial, as the cement industry makes 3.4 billion tons of cement annually, contributes $5 \%$ of all $\mathrm{CO}_{2}$-emissions caused by human activity (25) and accounts for $2 \%$ of global energy consumption (23).

The present study was performed in the "ZeroWaste" development area at the Department of Civil Engineering of the Technical University of Denmark (DTU) (26), which was intended to develop new construction materials based on partial replacement of ordinary material constituents with secondary resources such as recycled materials. Characterization of two ashes and their effect on selected physical properties of mortar were described in a previous part of the study (27).. The aim of the present work is to comprehensively assess the effect of cement replacement by two specific SSAs at different replacement ratios and with two ash pre-treatment methods on the heat and moisture transport properties of mortar.

\section{Materials and Methods}

\section{Material samples}

\section{Mortar mixture}

SSAs from two different locations were used in this study as a partial replacement material for cement. One type of SSA originated from a wastewater treatment plant in "Avedøre", while the other was from "Lynetten". Both of these plants are located near Copenhagen, Denmark. The plants treat wastewater from 17 municipalities that together serve approx. 1 375000 inhabitants.

As a reference material (REF), cement-based mortar samples (being mixtures of water, cement and sand) were prepared according to the standard (28) with the water-cement ratio kept constant at 1:2 for all mixtures. The same recipe was used for cement-ash-based mortars in which the cement content was partly replaced by the specific ashes, with mixtures and substitutions as shown in Table 1 . After casting and curing for 24 hours in a moist atmosphere, the samples were demoulded and the mortar monoliths were cured for 28 days in water at a constant temperature of $20 \pm 1^{\circ} \mathrm{C}$. The samples were then stored and dried in an oven at $45^{\circ} \mathrm{C}$. 


\section{Pre-treatment of ashes}

Two different pre-treatment methods were applied to the ashes: grinding or water washing. As reported in $(27,29)$, a simple ash pre-treatment can improve the compressive strength of the mortar.

Water washing of the SSA consisted of 3-washing cycles in distilled water. In a 1L-plastic bottle, $100 \mathrm{~g}$ of ash was mixed with $500 \mathrm{ml}$ of distilled water and agitated for $1 \mathrm{~min}$. Afterwards, the bottle was placed in a vertical position until the SSA settled. When settled, water was decanted and the bottle was refilled with a new dose of distilled water. This procedure was repeated 3 times. During the last cycle, water and the SSA were decanted through a filter paper $(11 \mu \mathrm{m})$. The wet ash was then dried in an oven at $105^{\circ} \mathrm{C}$ for at least $24 \mathrm{~h}$, and after cooling it was ready for use.

The other pre-treatment method was ash grinding. In this case, ash was ground for 30 seconds to achieve a finer particle size, using a Vibrating Cup Mill Pulverisette 9. After grinding, the ash was dried in the oven at $105^{\circ} \mathrm{C}$, and after cooling it was used in the mortar production.

Table 1 A matrix of mortar mixtures used in the study. The designations of the samples derive from their origin (Avedøre, AVE, or Lynetten, LYN), their substitution ratio (10 or 30) and the pre-treatment applied (Grinding, G, or Water-washing, W).

\begin{tabular}{llll}
\hline Name & $\begin{array}{l}\text { Substitution ration } \\
{[\%]}\end{array}$ & Ash origin & Pre-treatment \\
\hline REF & 0 & X & X \\
AVE 10G & 10 & AVE & G \\
AVE 10W & 10 & AVE & W \\
LYN 10G & 10 & LYN & G \\
LYN 10W & 10 & LYN & W \\
AVE 30G & 30 & AVE & G \\
AVE 30W & 30 & AVE & W \\
LYN 30G & 30 & LYN & G \\
LYN 30W & 30 & LYN & W \\
\hline
\end{tabular}




\section{Experimental methods}

\section{Drying}

The samples were dried either in an electrical oven or in a desiccator with silica gel. The samples used for sorption tests in the climatic chambers were exposed to different environments in order to determine their dry mass under various conditions. Prior to the sorption experiment, the samples were dried in an oven at $45^{\circ} \mathrm{C}$. Approximately 1.5 years after the sorption experiment, the samples were again dried, but now in various environments:

- in a sealed desiccator with silica gel at $20^{\circ} \mathrm{C}$,

- in a ventilated oven with silica gel inside at $45^{\circ} \mathrm{C}$,

- in a ventilated oven at $105^{\circ} \mathrm{C}$, and

- in a ventilated climatic chamber with a silica gel bag inside at $20^{\circ} \mathrm{C}$ (in contrast to the desiccator method, $\mathrm{CO}_{2}$ access was not limited).

Samples were not exposed initially to more than $45^{\circ} \mathrm{C}$, to avoid possible structural changes due to their exposure to elevated temperatures and to ensure that the material was exposed to conditions relevant for typical central-European indoor climates. Mass changes were captured by regular weighing using a Sartorius Research R 300 S microbalance with an accuracy of $\pm 0.02 \mathrm{mg}$.

\section{Thermal conductivity and volumetric heat capacity}

The thermal conductivity and volumetric heat capacity were determined under laboratory conditions at an average temperature of $24{ }^{\circ} \mathrm{C}$ using a heat transfer analyser, ISOMET 2104. Measurements were performed with a surface probe with a disc sensor. The specific heat capacity $c_{\mathrm{p}}[\mathrm{J} /(\mathrm{kg} \mathrm{K})]$ was calculated by dividing the measured volumetric heat capacity $C_{p}\left[\mathrm{~J} /\left(\mathrm{m}^{3} \mathrm{~K}\right)\right]$ by the measured density $\rho\left[\mathrm{kg} / \mathrm{m}^{3}\right]$. Dry and conditioned samples of dimensions $30 \times 30 \times 3 \mathrm{~cm}$ were examined at 5 surface points. The measuring accuracy was according to the producer: $10 \%$ of the reading for thermal conductivity in the range $0.7-6.0 \mathrm{~W} /(\mathrm{m} \cdot \mathrm{K})$ and $15 \%$ of the reading for volumetric heat capacity - around $1 \cdot 10^{3} \mathrm{~J} /\left(\mathrm{m}^{3} \mathrm{~K}\right)$.

\section{Sorption and moisture fixation}

The hygroscopic sorption properties were measured in accordance with the standard (30). Moisture storage in the hygroscopic range was determined by exposing the samples to various levels of relative humidity $(\mathrm{RH})$. Once equilibrium had been reached, moisture content was determined by weighing. The standard specifies two alternative methods that can be used, i.e. the desiccator method and the climatic chamber method. In this study, both methods were applied and were compared. For both of the sorption tests, samples were crushed into pieces of a few $\mathrm{mm}$ (up to $5 \mathrm{~mm}$ ) in maximum size and placed in glass cups (three cups per sample) or in inert textile bags (three bags per sample). All samples were dried in an oven at $45^{\circ} \mathrm{C}$ prior to the experiment ( $\mathrm{RH}$ in the oven was approximately $10 \%)$. RH levels set in the climatic chamber were the following: $11 \%$, $30 \%$, $50 \%, 70 \%$, $85 \%, 93 \%$ and $96 \%$; and in the desiccators it was: $33 \%, 58 \%, 75 \%$, 86 \% and $94 \%$. In 
the climatic chamber, only the adsorption isotherm was determined, so the RH level increased once equilibrium had been reached. In contrast, the samples in the glass desiccators were exposed to a high level of RH (100\%) first and RH levels were then progressively reduced in order to determine the desorption isotherms. The samples from the desiccators were then dried in an oven $\left(45^{\circ} \mathrm{C}\right)$ and subjected to moisture uptake in an adsorption process.

\section{Water vapour permeability}

The water vapour permeability was determined experimentally using the cup method to create a relative humidity gradient in such a way that a steady one dimensional transport across the samples was attained, as described in the standard (31). In dry cup tests, silica gel was used as a desiccant to achieve low $\mathrm{RH}$ close to $0 \%$, while Potassium nitrate $\left(\mathrm{KNO}_{3}\right)$ was used to generate a high relative humidity of $93 \% \pm 0.66 \% \mathrm{RH}$ in the wet cups. All the assemblies were placed in a temperature and humidity controlled chamber and exposed to constant conditions of temperature $23 \pm 1^{\circ} \mathrm{C}$ and relative humidity $53 \pm 3$ $\% \mathrm{RH}$. By regular weighing, the rate of water vapour transmission was determined. Based on the results determined from the first measurements (on 3-months old samples), the dry cup test was repeated a year after the first dry cup tests. The material parameters were expressed in terms of the water vapour permeance $\mathrm{W}[\mathrm{kg} /(\mathrm{s} \mathrm{Pa})]$ (Eq. 1) and water vapour permeability $\delta[\mathrm{kg} /(\mathrm{m} \mathrm{s} \mathrm{Pa})]$ (Eq. 2). The resistance of the air layer was not considered since the air layer resistance is negligible compared to the resistance of the mortar $(\mathrm{W}=$ $\mathrm{x} 10^{-12} \mathrm{~kg} /(\mathrm{s} \mathrm{Pa})$ (air) and $\times 10^{-10} \mathrm{~kg} /(\mathrm{s} \mathrm{Pa})$ (mortar), $\delta=\times 10^{-10} \mathrm{~kg} /(\mathrm{m} \mathrm{s} \mathrm{Pa})$ (air) and $\times 10^{-12}$ $\mathrm{kg} /(\mathrm{m} \mathrm{s} \mathrm{Pa})$ (mortar), respectively).

$$
\begin{aligned}
& W=\frac{G}{A \cdot \Delta p_{v}} \\
& \delta=W \cdot d
\end{aligned}
$$

- where $G[\mathrm{~kg} / \mathrm{s}]$ is the moisture mass change rate, $A\left[\mathrm{~m}^{2}\right]$ is the transmission area, $\Delta p_{v}[\mathrm{~Pa}]$ is the vapour pressure difference over the sample and $d[\mathrm{~m}]$ is the thickness of the sample.

\section{Carbonation test}

Dry mortar samples were ground into "flour-like" powder and immersed in a hydrochloric acid $(\mathrm{HCl})$ solution. Calcium carbonate $\mathrm{CaCO}_{3}$, a product of carbonation, reacted with hydrochloric acid to form calcium chloride $\left(\mathrm{CaCl}_{2}\right)$, carbon dioxide $\left(\mathrm{CO}_{2}\right)$ and water. The concentration of $\mathrm{CO}_{2}$ was measured and based on that the content of $\mathrm{CaCO}_{3}$ was calculated.

Table 2 Characterization of samples used in the carbonation test

Name Description

New I Freshly cast samples, cured for 28 days in water, then dried and tested

New II The same batch as New I but 1 month older, dried in an oven at $45^{\circ} \mathrm{C}$ 
New III The same batch as New I, dried in an oven at $45^{\circ} \mathrm{C}$, exposed to $50 \% \mathrm{RH}$ for 8 weeks before carbonation test took place

\section{Results}

\section{Drying methods}

The dry mass of the mortar specimens presented in Table 3 show that the most effective drying took place at the beginning of the experiment, immediately after the samples had been taken out of the water curing bath. None of the other methods achieved a lower dry mass compared to the initial drying.

Comparing the amount of moisture released in the given condition, cement-based mortar (REF) had the lowest ability to release the moisture compared to the mortar samples containing $70 \%$ cement and $30 \%$ SSA. The ability to release the moisture content increased with the ash to cement ratio. No effect of ash type or ash pre-treatment was observed.

Table 3 Average weight difference in [\%] of three mortar specimens based on different drying methods compared to the initial drying in the oven at $45^{\circ} \mathrm{C}(*)$, SD standard deviation

\begin{tabular}{|c|c|c|c|c|c|c|c|c|c|}
\hline \multirow[b]{2}{*}{ Material } & \multirow{2}{*}{$\begin{array}{l}\text { Oven } \\
45^{\circ} \mathrm{C} \\
* \\
\\
{[g]}\end{array}$} & \multicolumn{2}{|c|}{$\begin{array}{l}\text { Desiccator } \\
+ \text { silica gel }\end{array}$} & \multicolumn{2}{|c|}{$\begin{array}{l}\text { Oven } 45^{\circ} \mathrm{C} \\
+ \text { silica gel }\end{array}$} & \multicolumn{2}{|c|}{ Oven $105^{\circ} \mathrm{C}$} & \multicolumn{2}{|c|}{$\begin{array}{l}\text { Climatic } \\
\text { chamber }+ \\
\text { silica gel } 4 \% \\
\text { RH }\end{array}$} \\
\hline & & [\%] & $\begin{array}{l}\text { SD } \\
{[\%]}\end{array}$ & [\%] & $\mathrm{SD}[\%]$ & [\%] & $\begin{array}{l}\text { SD } \\
{[\%]}\end{array}$ & [\%] & $\mathrm{SD}[\%]$ \\
\hline REF & 17.5 & 4.6 & 0.29 & 4.2 & 0.01 & 3.0 & 0.25 & 3.2 & 0.32 \\
\hline $\begin{array}{l}\text { AVE } \\
30 G\end{array}$ & 19.1 & 3.0 & 0.28 & 3.1 & 0.23 & 2.3 & 0.34 & 2.1 & 0.19 \\
\hline $\begin{array}{l}\text { AVE } \\
30 W\end{array}$ & 21.2 & 3.0 & 0.05 & 3.2 & 0.05 & 2.5 & 0.09 & 2.4 & 0.18 \\
\hline $\begin{array}{l}\text { LYN } \\
30 G\end{array}$ & 19.3 & 3.0 & 0.18 & 3.2 & 0.16 & 2.2 & 0.14 & 1.8 & 0.25 \\
\hline
\end{tabular}


*Weight of mortar samples immediately after initial drying in an oven at $45^{\circ} \mathrm{C}$ (drying performed immediately after 28-days curing in a water bath)

\section{Thermal conductivity and specific heat capacity}

Figure 1 shows the relation between the porosity of the mortar and its thermal conductivity. Mortar porosity was clearly influenced by ash content. A coarser ash texture than the fine cement resulted in a higher porosity in the mortar containing ash compared to the REF. The grain size distributions of cement and ashes, their chemical composition and their ability to hydrate, all have significant effects on mortar porosity. These findings were reported in (27).

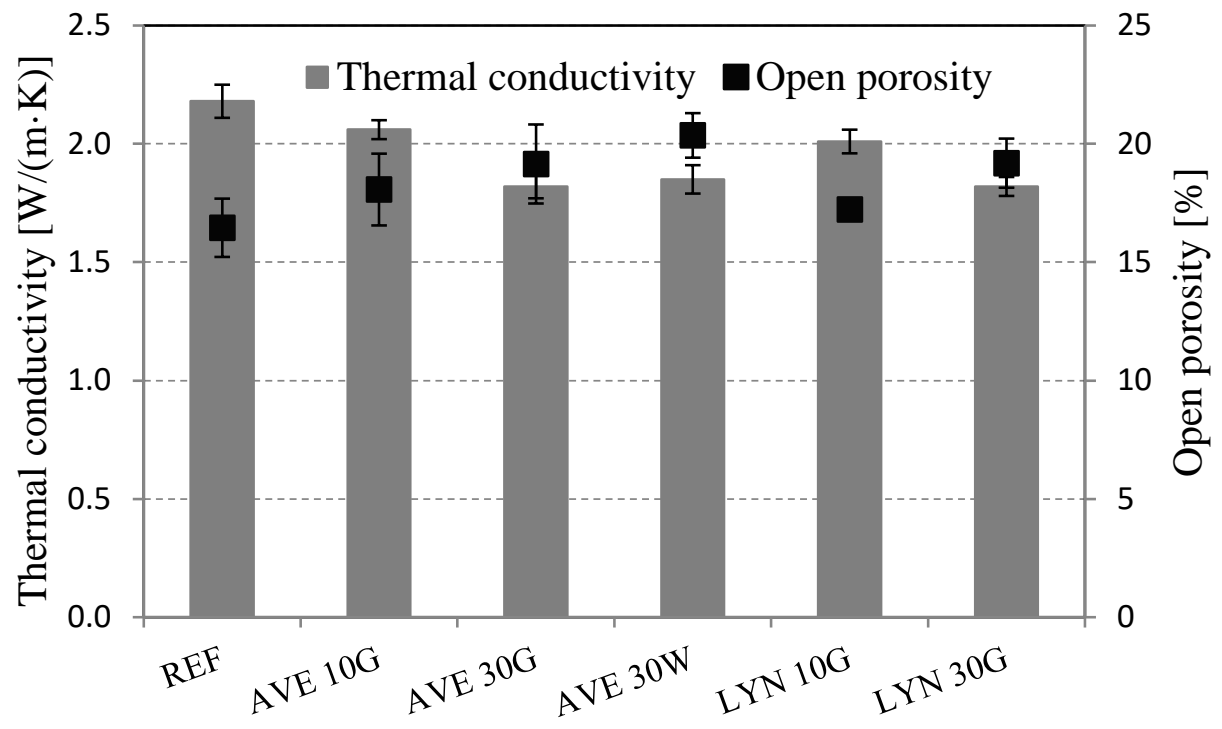

Figure 1 Average values and standard deviations of three duplicates for thermal conductivity and porosity, graphical relation

The thermal conductivity and specific heat capacity results are shown in Table 4. As expected, thermal conductivity increased with decreasing porosity as the insulating ability of air is greater than that of the solid constituents of mortar. Specifically, the reference material with $0 \%$ ash has the highest ability to conduct heat compared to the mortar containing ash. Replacement of $30 \%$ of the cement by ash led to an approximately $15 \%$ decrease in the thermal conductivity, which may be an additional advantage for cement substitution. No significant differences in terms of these measurements were observed between the two ashes or between their pre-treatment methods. 
Table $4 \quad$ Average values of three duplicates for thermal conductivity $\lambda$ and specific heat capacity $\mathrm{C}_{\mathrm{p}}$ measured by the surface probe of a heat transfer analyser, SD - standard deviation

\begin{tabular}{lllll}
\hline Material & $\lambda[\mathrm{W} / \mathrm{m} \cdot \mathrm{K}]$ & $\mathrm{SD}$ & Diff $[\%]$ & $\mathrm{C}_{\mathrm{p}}[\mathrm{J} / \mathrm{kg} \cdot \mathrm{K}]$ \\
\hline REF & 2.18 & 0.07 & --- & 821 \\
AVE 10G & 2.06 & 0.04 & -5.5 & 822 \\
AVE 30G & 1.82 & 0.05 & -16.5 & 806 \\
AVE 30W & 1.85 & 0.06 & -15.1 & 808 \\
LYN 10G & 2.01 & 0.05 & -7.8 & 813 \\
LYN 30G & 1.82 & 0.04 & -16.5 & 814 \\
\hline
\end{tabular}

\section{Sorption and analyses of moisture fixation}

Equilibrium moisture content for specific mortar compositions was measured by two experimental setups: in a climatic chamber and in glass desiccators. Results obtained in tests are presented in this subsection.

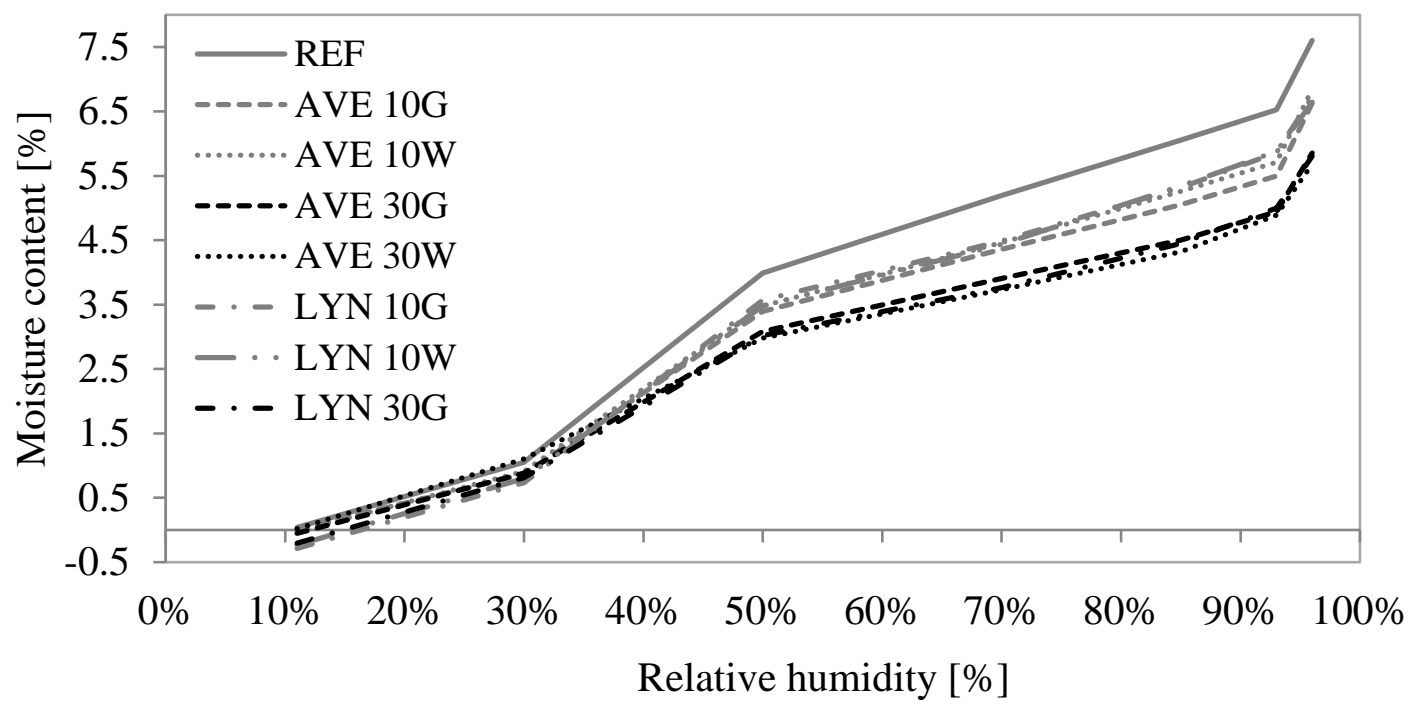

Figure 2 Sorption isotherms of the mortar samples performed in the climatic chamber based on average values of three duplicates

In Figure 2, exposure to low RH in the adsorption test in the climatic chamber, i.e. at $11 \%$ $\mathrm{RH}$, shows that the moisture content of the mortar remained unchanged or even slightly 
decreased in all the samples compared to its state after initial drying in an oven at $45^{\circ} \mathrm{C}$. This indicates that the moisture content in the samples initially after drying was higher than or equal to the equilibrium moisture content at the first $\mathrm{RH}$-value imposed in the climatic chamber during the sorption test, i.e. at $11 \% \mathrm{RH}$. The reference material, REF, without ash content is clearly characterized by having the highest moisture content at all RH levels compared to the specimens containing $10 \%$ or $30 \%$ of ash. This difference became more pronounced with increasing $\mathrm{RH}$ level. In general, for increasing ash to cement ratio, the moisture content became lower. No clear effects of the type of ash or the ash pre-treatment were found.
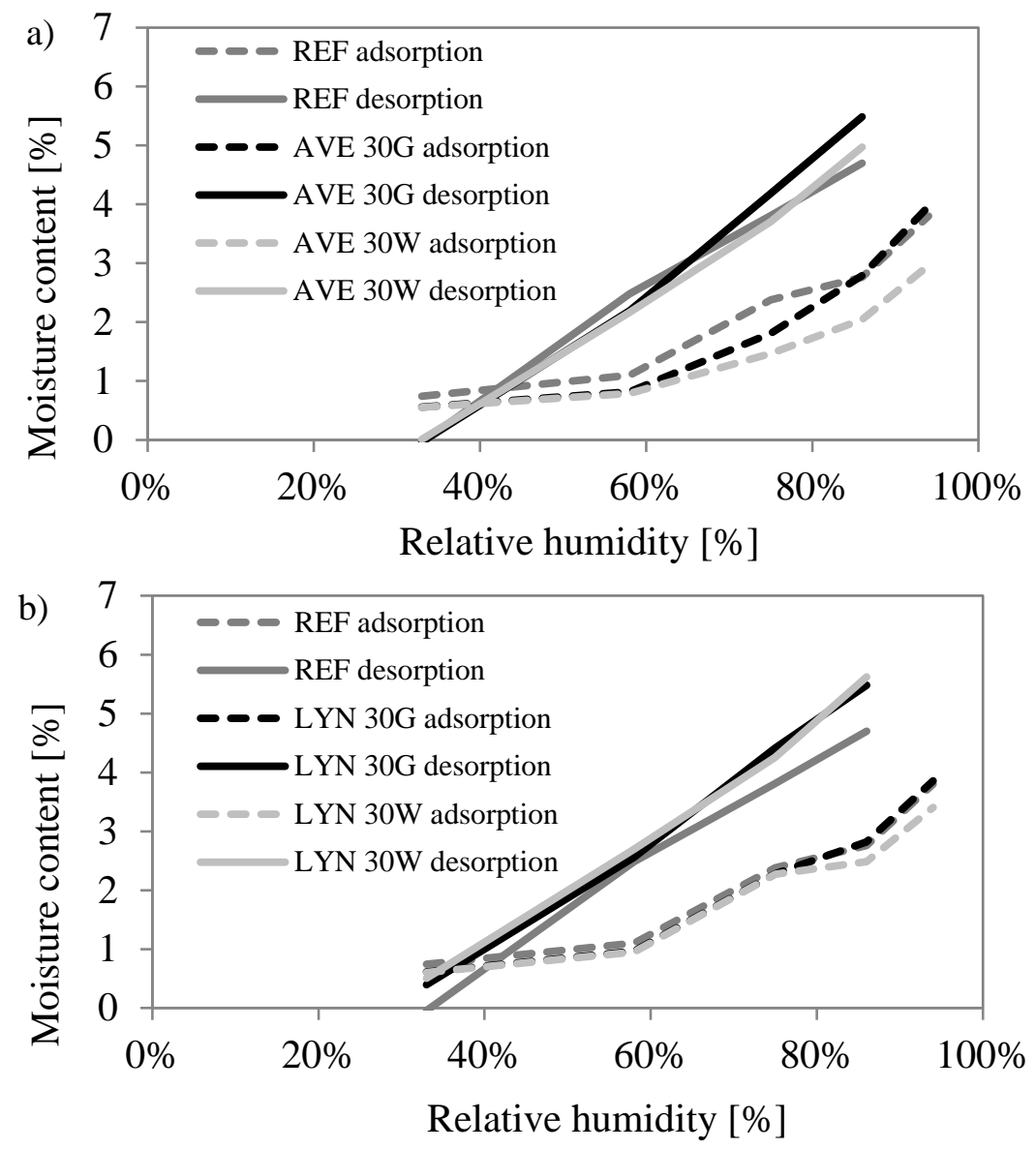

Figure 3 Sorption hysteresis of the mortar samples performed in the desiccators a) comparison of cement-based mortar (REF) and mortar with $30 \%$ cement replacement by Avedøre ash (AVE); b) comparison of cement-based mortar (REF) and mortar with $30 \%$ cement replacement by Lynetten ash (LYN).

Figure 3 shows the adsorption and desorption isotherms of hardened mortars, comparing REF mortar with mortar containing Avedøre or Lynetten ash as a partial cement replacement.. Comparing the different mortar compositions, the graphs show that the sorption or desorption curves coincide with each other over the greater part of the relative 
humidity, although some differences can be observed at high humidity. Only small differences or no difference at all were found between the different ash pre-treatments. However, a slightly higher sorption ability is evident for mortar with AVE30G, which reached the level of cement-based mortar at RH levels above $80 \%$.

\section{Water vapour permeability}

Measurements of the water vapour permeability are shown in Fig. 4. Comparing the different mortar compositions, the water vapour permeability increased with the ash to cement ratio. Comparing pre-treatment methods, the results show that using ground ash with a finer ash structure kept the open porosity lower, so the permeability remained lower.

An analysis of results from the dry cup tests and its repetition one year later showed a significant decrease in the water vapour permeability with the age of the cementitious material. This may be due to the microstructural evolution of the cementitious material (e.g. porosity and tortuosity) resulting from the processes of hydration and carbonation. 


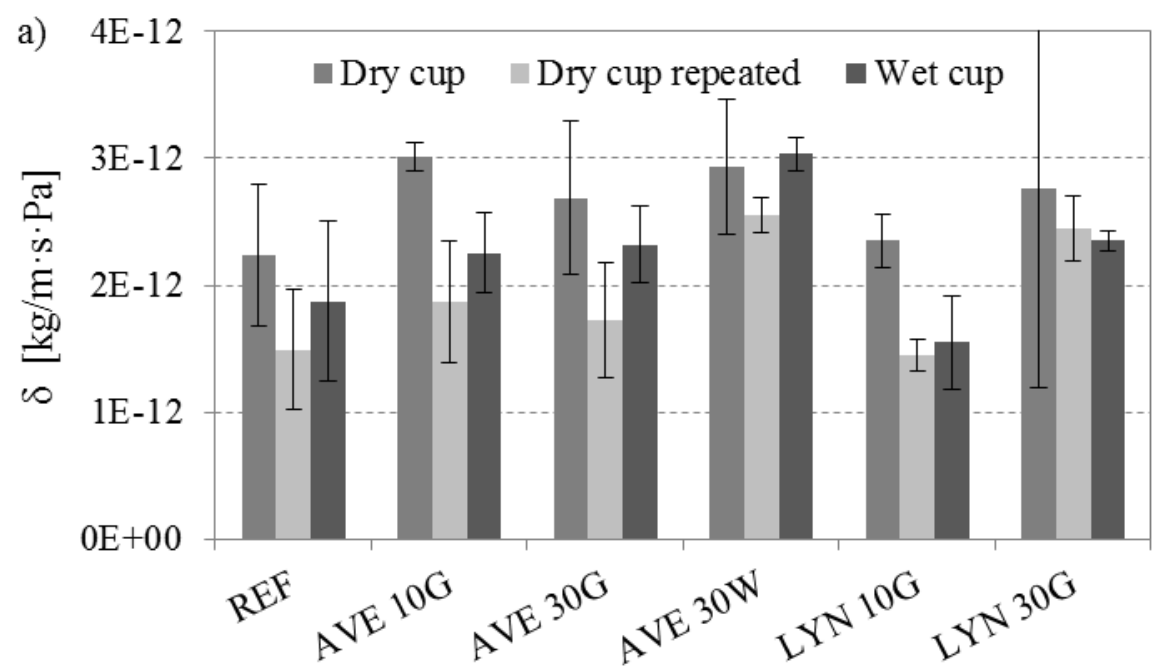

\begin{tabular}{llll}
\hline b) & \multicolumn{3}{c}{ Difference [\%] } \\
& Dry cup & $\begin{array}{c}\text { Dry cup } \\
\text { repeated }\end{array}$ & Wet cup \\
\hline REF & 0.0 & 0.0 & 0.0 \\
AVE 10G & 34.6 & 25.7 & 20.3 \\
AVE 30G & 20.3 & 15.8 & 23.8 \\
AVE 30W & 31.3 & 70.9 & 62.0 \\
LYN 10G & 5.0 & -2.8 & -17.4 \\
LYN 30G & 23.5 & 64.2 & 25.4 \\
\hline
\end{tabular}

Figure $4 \quad$ a) Average values of three duplicates for water vapour permeability $\delta$ $[\mathrm{kg} /(\mathrm{m} \cdot \mathrm{s} \cdot \mathrm{Pa})]$ of the mortar samples and standard deviation (SD), b) percentage difference of samples containing ash compared to cement-based mortar (REF)

\section{Carbonation test}

Figure 5 shows the calcium carbonate content in newly-cast mortars that were prepared for the purpose of carbonation test and had never been used in other tests. The observations show that the initial calcium carbonate content in 'New I' varied between $12.2-13.1 \%$ and thus its level was similar for all mortar samples regardless of their ash content. 


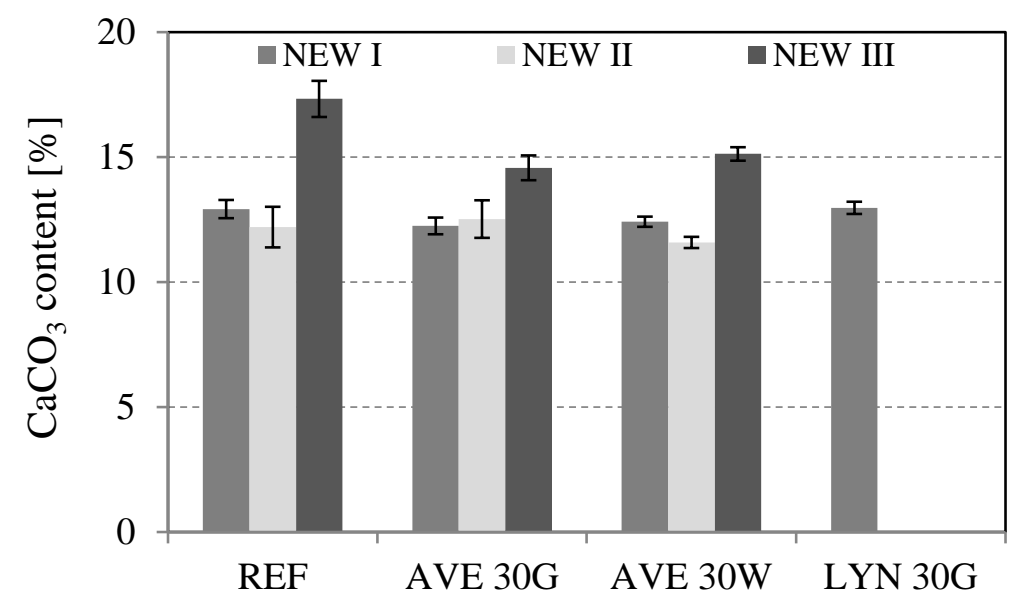

Figure 5 Results of the carbonation test shown as $\mathrm{CaCO}_{3}$ content in mortar samples.

The content of calcium oxide (CaO) naturally occurring in cement and in the SSAs may potentially form $\mathrm{CaCO}_{3}$ in reaction with $\mathrm{CO}_{2}$ (Eq. 3), resulting in similar amounts of calcium carbonate $\left(\mathrm{CaCO}_{3}\right)$ content in mortar with and without ash (27). Comparison of 'New I' and 'New II' shows that drying in the oven slightly affected carbonate content. While exposure to $50 \% \mathrm{RH}$ for 8 weeks had a significant impact on mortar carbonation, the calcium carbonate content increased by $2.1-2.5 \%$ steps in samples containing $30 \%$ of Avedøre ash and by $5.1 \%$ steps in cement-based mortar samples (REF). Separate carbonation tests indicate that this reaction takes place quite fast.

$\mathrm{CaO}+\mathrm{CO}_{2} \rightleftarrows \mathrm{CaCO}_{3}(3)$

(reversible at high temperature above $825^{\circ} \mathrm{C}$ ) (32)

\section{Discussion}

The dry weight of samples is a central parameter for the determination of hygrothermal properties. Without knowledge of the dry mass it is impossible to define many parameters such as porosity, density, the moisture content, water vapour permeability, water retention, etc. However, in the case of cementitious materials, the dry state is not clearly defined. Cementitious materials naturally contain water that is either bonded in the structure in the form of a C-S-H gel and portlandite $\mathrm{Ca}(\mathrm{OH})_{2}$, or which is physically present in the pores (33), so depending on the drying method, different amounts of water can be expelled. Some studies, e.g. $(34,35)$, refer to the drying temperature set to $105{ }^{\circ} \mathrm{C}$. Such an elevated temperature may however cause structural change to the material. For the purpose of the current study with its focus on the interaction of mortar with indoor climate, the drying temperature was initially set to $45^{\circ} \mathrm{C}$. Based on the observations, the most effective drying was achieved at the beginning of the experimental testing, just after the samples had been cured. Furthermore, the higher the temperature applied, the better drying results were observed. 
Determination of basic material parameters, such as porosity, is an integral part of the material characterization and should not be omitted when reporting on the hygrothermal performance. The present study reports only on open porosity in relation to the thermal conductivity of mortar samples. More detailed results can be found in (27). The open porosity affects the following hygrothermal properties most: a) The thermal conductivity, which decreases as the open porosity increases. Pores filled with air serve as thermal insulation, and thus decrease the overall thermal conductivity of the mortar. In addition, the thermal conductivity of SSA has been observed to be lower than that of pure cement paste (36). b) Similar observations were made for the water vapour permeability, which was clearly higher for mortars with high ash content. Moreover, it may be concluded that grinding the ash before casting the mortar resulted in lower open porosity of the mortar, which have led to a significant decrease in the permeability of the material compared to the water-wash pre-treatment.

The adsorption and desorption isotherms are required to predict the hygroscopic water content in cementitious materials under changing climatic conditions. It has been shown that hysteresis between the adsorption and desorption isotherms of cementitious materials is significant (37), and so it was for the mortars analysed in the present paper. Sorption thermodynamics and the particular pore structure of cementitious materials determine the sorption behaviour. Since the pore structure changes during the hydration of cement (38), during the drying-process (39), and during chemical aging (40), it could be expected that it also affects the sorption properties. Determination of sorption isotherms that was performed in climatic chambers showed that the amount of moisture adsorbed was higher for the mortar samples with low porosity. The water vapour was adsorbed by the cement constituent and reacted with the $\mathrm{CO}_{2}$ supplied to the climate chamber, together with moist air, to produce calcium carbonate, $\mathrm{CaCO}_{3}$. Carbonation is a natural process that occurs in moist air with access to $\mathrm{CO}_{2}$, and the highest carbonation rate occurs at $50-80 \% \mathrm{RH}$ (41). This reaction may result in a greater increase in mass change when comparing the two sorption test methods applied, i.e. the climatic chamber method (Fig. 2) and the glass desiccators (Fig. 3). For example, cement-based mortar reached $6.5 \%$ mass gain due to carbonation, compared to dry mass, when measured with the climatic chamber method, and only $4 \%$ mass gain when measured in a desiccator. The results obtained in the sorption tests performed in the climatic chambers corroborate the results on cement and ash sorption isotherms reported in (27). The sorption isotherm of cement was located significantly above the sorption isotherms of the ashes, so larger mass gains for cement were observed compared to that of any type of ash, regardless of which pre-treatment method was applied. This indicates that sorption ability may be affected by the potential reactivity of cement/ash with water, which is obviously higher for the cement.

In contrast, the sorption isotherms obtained in the tests in the glass desiccators show a slightly different adsorption ability, one that was dependent on the percentage of cement replacement. Isotherms obtained from desiccators (when the desorption test was performed before the adsorption test) coincided with each other independently of the mortar composition. Similar results were observed in (42) when cement-based mortar was 
compared with mortar where a proportion of the cement (30\%) had been replaced with blast furnace slag. It was reported that the adsorption/desorption isotherms of samples with the same age showed only minor differences between these materials. However, it is not easy to assess the hygroscopic properties of cementitious materials, as in addition to the capillary effect between condensation and evaporation in the pores, according to the Kelvin equation, the chemical water uptake, the drying process, and chemical aging may affect the observed values.

Summarizing the results achieved by different sorption methods, the observed differences between the isotherms may have been caused by changes in the material structure, which occur as a result of the chemical aging and carbonation that take place in parallel with the weight gain by water vapour adsorption. Even though cement and ash show different sorption activity (27), replacement of cement by $30 \%$ of SSA did not lead to any significant effect on the sorption ability of the final product, i.e. on the mortar. The aging of the material and its reactivity with adsorbed water and the carbon dioxide present in the climatic chamber caused differences to be observed between samples containing $0 \%$ and $30 \%$ of ash. The climatic chamber method was chosen in order to simulate most credibly the indoor environment, where $\mathrm{CO}_{2}$ is present. It seems that experimentally this is the weakness of using the climatic chamber method for the determination of the sorption properties of cementitious materials. Detailed examination of the carbonation process in the material sample is difficult due to the various factors that affect carbonation rate and the methods used to examine it. The climate chamber method with open $\mathrm{CO}_{2}$ access is therefore not recommended for assessing cementitious materials if it is required that the measurements should be unaffected by the $\mathrm{CO}_{2}$ concentration, as was also recommended in $(43,44)$.

An effect of the structural changes was also shown in the repeated permeability test in which the dry cup water vapour permeability test was repeated after 1 year. Except for the first dry cup test when samples had been newly cast and dried, the samples were stored for a year in a test chamber with a normal indoor environment and thus came into contact with moisture and $\mathrm{CO}_{2}$. Comparing the first and the second dry cup test taken 1 year later, the measured permeability decreased for all the samples tested. This is in accordance with the theory of Pham and Prince (45) that small pores are clogged by calcium carbonate while the distribution of mesopores increases simultaneously.

In general, it can be concluded that partial replacement of cement by SSA has the effect on hygrothermal properties of mortar especially those properties directly related to mortar structure (porosity) and at higher cement replacement ratios (30\%). Cement replacement by up to $10 \%$ can be a good compromise of slightly changed mortar properties and beneficial contribution to $\mathrm{CO}_{2}$ reduction related to decreased cement consumption. 


\section{Conclusions}

- The most effective drying was achieved with new samples of mortar prior to all experiments.

- Lower thermal conductivity and higher vapour permeability may be a result of higher mortar porosity due to the larger grain size of SSA compared to cement.

- The thermal conductivity of mortar was reduced by $15 \%$ when $30 \%$ of the cement was replaced by SSA.

- Sorption was influenced by the test method used. Differences between cementbased and cement-ash-based mortar could be seen when samples were exposed to air containing $\mathrm{CO}_{2}$.

- The calcium carbonate content was shown to be higher for cement-based mortar compared to cement-ash-based mortar.

- Carbonation of mortar and its consequences must be considered not only in the process of data processing but already in the experimental procedure and time planning. The age of the samples may influence the parameters of cementitious materials considerably.

\section{References}

1. Naamane S, Rais Z, Taleb M. The effectiveness of the incineration of sewage sludge on the evolution of physicochemical and mechanical properties of Portland cement. Construction and Building Materials. 2016;112:783-9.

2. Cyr M, Coutand M, Clastres P. Technological and environmental behavior of sewage sludge ash (SSA) in cement-based materials. Cement and Concrete Research. 2007 Aug;37(8):1278-89.

3. Murakami T, Suzuki Y, Nagasawa H, Yamamoto T, Koseki T, Hirose H, et al. Combustion characteristics of sewage sludge in an incineration plant for energy recovery. Fuel Processing Technology. 2009 Jun;90(6):778-83.

4. Donatello S, Cheeseman CR. Recycling and recovery routes for incinerated sewage sludge ash (ISSA): A review. Waste Management [Internet]. 2013 [cited 2013 Aug 26]; Available from: http://www.sciencedirect.com/science/article/pii/S0956053X13002559

5. Ahmaruzzaman M. A review on the utilization of fly ash. Progress in Energy and Combustion Science. 2010 Jun;36(3):327-63.

6. Chen M, Blanc D, Gautier M, Mehu J, Gourdon R. Environmental and technical assessments of the potential utilization of sewage sludge ashes (SSAs) as secondary raw materials in construction. Waste Management. 2013 May;33(5):1268-75.

7. Ottosen LM, Jensen PE, Kirkelund GM. Phosphorous recovery from sewage sludge ash suspended in water in a two-compartment electrodialytic cell. Waste Management. 2016 May;51:142-8. 
Postprint of article published in Journal of Building Physics 2019, Vol. 42(6) 771-787

DOI: $10.1177 / 1744259118791202$

8. Ing DS, Chin SC, Guan TK, Suil A. The use of sewage sludge ash (SSA) as partial replacement of cement in concrete. ARPN Journal of Engineering and Applied Sciences. 2016;11(6):3771-5.

9. Lynn CJ, Dhir RK, Ghataora GS, West RP. Sewage sludge ash characteristics and potential for use in concrete. Construction and Building Materials. 2015 Nov 15;98:767-79.

10. Monzó J, Payá J, Borrachero MV, Córcoles A. Use of sewage sludge ash(SSA)cement admixtures in mortars. Cement and Concrete Research. 1996 Sep;26(9):1389-98.

11. Monzó J, Payá J, Borrachero MV, Girbés I. Reuse of sewage sludge ashes (SSA) in cement mixtures: the effect of SSA on the workability of cement mortars. Waste Management. 2003;23(4):373-81.

12. Yusuf RO, Noor ZZ, Moh' NA, Moh' d F, Din d, Abba AH. Use of sewage sludge ash (SSA) in the production of cement and concrete - a review. International Journal of Global Environmental Issues. 2012;12(2/3/4):214.

13. Halliday JE, Jones MR, Dyer TD, Ravindra K. Dhir. Potential use of UK sewage sludge ash in cement-based concrete. Proc Inst Civ Eng: Waste Res Manage Proceedings of the ICE - Waste and Resource Management. 2012;165(2):57-66.

14. Pérez-Carrión M, Baeza-Brotons F, Payá J, Saval JM, Zornoza E, Borrachero MV, et al. Potential use of sewage sludge ash (SSA) as a cement replacement in precast concrete blocks. Materiales de Construcción. 2014 Mar 30;64(313):002.

15. Smol M, Kulczycka J, Henclik A, Gorazda K, Wzorek Z. The possible use of sewage sludge ash (SSA) in the construction industry as a way towards a circular economy. Journal of Cleaner Production. 2015 May 15;95:45-54.

16. Wiebusch B, Seyfried CF. Utilization of sewage sludge ashes in the brick and tile industry. Water Science and Technology. 1997;36(11):251-8.

17. Donatello S. Characteristics of incinerated sewage sludge ashes: potential for phosphate extraction and re-use as a pozzolanic material in construction products [PhD Thesis]. [London]: Imperial College, Department of Civil and Environmental Engineering; 2009.

18. Garcés P, Pérez Carrión M, García-Alcocel E, Payá J, Monzó J, Borrachero MV. Mechanical and physical properties of cement blended with sewage sludge ash. Waste Management. 2008 Dec 1;28(12):2495-502.

19. Lin KL, Chang WC, Lin DF, Luo HL, Tsai MC. Effects of nano-SiO2 and different ash particle sizes on sludge ash-cement mortar. Journal of Environmental Management. 2008 Sep;88(4):708-14.

20. Baeza-Brotons F, Garcés P, Payá J, Saval JM. Portland cement systems with addition of sewage sludge ash. Application in concretes for the manufacture of blocks. Journal of Cleaner Production. 2014 Nov 1;82:112-24.

21. Eliche-Quesada D, Martínez-García C, Martínez-Cartas ML, Cotes-Palomino MT, Pérez-Villarejo L, Cruz-Pérez N, et al. The use of different forms of waste in the manufacture of ceramic bricks. Applied Clay Science. 2011 May;52(3):270-6.

22. Weng C-H, Lin D-F, Chiang P-C. Utilization of sludge as brick materials. Advances in Environmental Research. 2003 May;7(3):679-85. 
23. Worrell E, Lynn Price, Nathan Martin, Chris Hendriks, Meida LO. Carbon Dioxide Emissions from the Global Cement Industry. Annual Review of Energy and the Environment. 2001;26(1):303-29.

24. Hasanbeigi A, Price L, Lin E. Emerging energy-efficiency and CO2 emissionreduction technologies for cement and concrete production: A technical review. Renewable and Sustainable Energy Reviews. 2012 Oct;16(8):6220-38.

25. Benhelal E, Zahedi G, Shamsaei E, Bahadori A. Global strategies and potentials to curb CO2 emissions in cement industry. Journal of Cleaner Production. $2013 \mathrm{Jul}$ 15;51:142-61.

26. ZeroWaste Byg [Internet]. http://www.zerowaste.byg.dtu.dk. [cited 2017 May 17]. Available from: http://www.zerowaste.byg.dtu.dk/

27. Krejcirikova B, Ottosen LM, Kirkelund GM, Peuhkuri R, Rode C. Characterization of sewage sludge ash and its effect on moisture physics of mortar. Unpublished results;

28. DS/EN 196-1:2005 Methods of testing cement - Part 1: Determination of strength [Internet]. 2005 [cited 2013 Aug 27]. Available from: http://sd.ds.dk.globalproxy.cvt.dk/extranet/viewer3.py?project_nr=50753\&status=6 0.60

29. Ottosen LM, Jensen PE, Goltermann P, Kirkelund GM. Sewage sludge ash as cement replacement after simple pretreatment. In: Proceedings of 14th International Waste Management and Landfill Symposium. Sardinia; 2013.

30. ISO 12571:2000 Hygrothermal performance of building materials and products Determination of hygroscopic sorption properties [Internet]. [cited 2013 May 2]. Available from: http://www.iso.org/iso/catalogue_detail.htm?csnumber=2408

31. ISO 12572:2001 Hygrothermal performance of building materials and products Determination of water vapour transmission properties.

32. Powers TC. A discussion of cement hydration in relation to the curing of concrete. Chicago: Portland Cement Association; 1948.

33. Pihlajavaara SE. Notes on the Drying of Concrete. First Edition edition. The Institute for Technical Research; 1963.

34. Abdelhamid MB, Mihoubi D, Sghaier J, Bellagi A. Water Sorption Isotherms and Thermodynamic Characteristics of Hardened Cement Paste and Mortar. Transp Porous Med. 2016 Apr 29;113(2):283-301.

35. Pham ST. Effects of Carbonation on the Microporosity and Macro Properties of Portland Cement Mortar CEM I. Journal of Materials Science and Chemical Engineering. 2014;02(07):40-52.

36. Wang K-S, Chiou I-J, Chen C-H, Wang D. Lightweight properties and pore structure of foamed material made from sewage sludge ash. Construction and Building Materials. 2005 Oct;19(8):627-33.

37. Espinosa RM, Franke L. Influence of the age and drying process on pore structure and sorption isotherms of hardened cement paste. Cement and Concrete Research. 2006 Oct;36(10):1969-84.

38. Lawrence CD. 8 - Physicochemical and Mechanical Properties of Portland Cements. In: Hewlett PC, editor. Lea’s Chemistry of Cement and Concrete (Fourth Edition) 
[Internet]. Oxford: Butterworth-Heinemann; 1998 [cited 2017 Oct 20]. p. 343-419. Available from:

https://www.sciencedirect.com/science/article/pii/B9780750662567500205

39. Beaudoin JJ, Tamtsia BT. Effect of Drying Methods on Microstructural Changes in Hardened Cement Paste: an A. C. Impedance Spectroscopy Evaluation. ACT. 2004;2(1):113-20.

40. Thomas JJ, Jennings HM. A colloidal interpretation of chemical aging of the C-S-H gel and its effects on the properties of cement paste. Cement and Concrete Research. 2006 Jan 1;36(1):30-8.

41. Tuutti K. Corrosion of steel in concrete. Vol. 1982:4. 1982.

42. Issaadi N, Nouviaire A, Belarbi R, Aït-Mokhtar A. Moisture characterization of cementitious material properties: Assessment of water vapor sorption isotherm and permeability variation with ages. Construction and Building Materials. 2015 May 15;83:237-47.

43. Johannesson B, Utgenannt P. Microstructural changes caused by carbonation of cement mortar. Cement and Concrete Research. 2001 May;31(6):925-31.

44. Pham ST. Modifications in Water Sorption Isotherms of Cement Mortars Caused by Carbonation: Effects of Cycles. Advanced Materials Research. 2014 Oct;1042:3-9.

45. Pham ST, Prince W. Effects of Carbonation on the Microstructure of Cement Materials: Influence of Measuring Methods and of Types of Cement. Int J Concr Struct Mater. 2014 Sep 2;8(4):327-33. 